\title{
PENGATURAN SUBSIDI PERIKANAN DALAM WTO DAN DAMPAKNYA BAGI INDONESIA
}

\author{
Hilton T. Putra* dan Eka An Aqimuddin** \\ Bagian Hukum Internasional, Fakultas Hukum Universitas Sultan Ageng Tirtayasa, Serang \\ Jalan Raya Jakarta KM 04 Pakupatan Kota Serang, Banten 42124 \\ Bagian Hukum Internasional, Fakultas Hukum Universitas Islam Bandung, Bandung \\ Jalan Ranggagading No. 8 Bandung, Jawa Barat 40116
}

\begin{abstract}
Fisheries subsidies have been practiced by many states in the world. Such actions are considered as one of the causes of over-fishing. Its also endanger sustainable fisheries management. There is no specific regulation on fisheries subsidies in the WTO. To date, negotiation over fisheries subsidies came out with the draft and it would be attach as Annexes VIII of SCM Agreement. The draft of fisheries subsidies specifically regulates prohibited subsidies, general exception and special and different treatment. The impact of the WTO fisheries subsidies draft will be negative to the Indonesian fisheries market, fishery resources and employment.
\end{abstract}

Keywords: WTO, fisheries subsidies, Indonesia.

\section{Intisari}

Subsidi perikanan telah dipraktikkan oleh negara-negara di dunia. Tindakan tersebut dianggap sebagai salah satu penyebab terjadinya eksploitasi sumber daya perikanan sehingga membahayakan pengelolaan perikanan berkelanjutan. Terkait dengan perdagangan dan subsidi perikanan, belum ada regulasi khusus tentang subsidi perikanan di WTO. Negosiasi di WTO hingga saat ini baru pada rancangan yang akan menjadi lampiran VIII SCM Agreement. Rancangan subsidi perikanan di WTO mengatur secara khusus tentang subsidi perikanan yang dilarang dan pengecualian secara umum. Dampak dari rancangan subsidi perikanan WTO tersebut apabila berhasil disahkan akan memberikan dampak negatif kepada Indonesia terkait dengan pasar perikanan, sumber daya perikanan dan lapangan pekerjaan.

Kata Kunci: WTO, subsidi perikanan, Indonesia.

\section{Pokok Muatan}

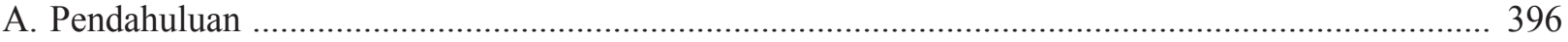

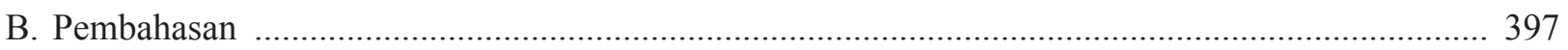

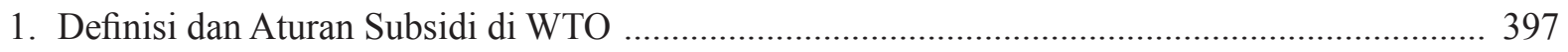

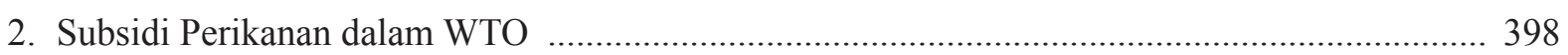

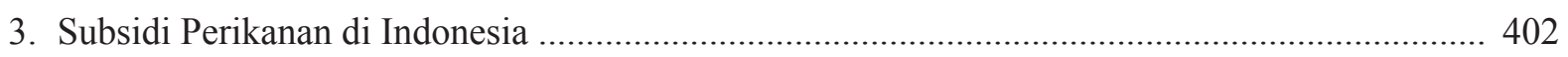

4. Subsidi Perikanan di WTO dan Dampaknya bagi Indonesia ........................................................ 404

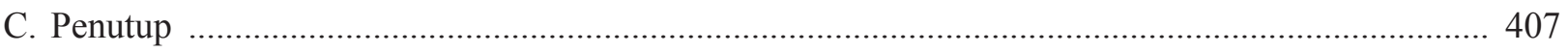

Alamat korespondensi: hiltonputra@yahoo.com

Alamat korespondensi: eka.aqimuddin@gmail.com 


\section{A. Pendahuluan}

Tujuan pembentukan World Trade Organization (WTO) dapat dilihat dalam bagian preambul The Agreement Establishing the World Trade Organization yang ditandatangani di Marrakesh, Maroko pada April 1994 dan mulai berlaku (entry into force) 1 Januari 1995. Pada bagian pembukaan perjanjian tersebut dinyatakan bahwa pendirian WTO bertujuan untuk; (1) meningkatkan standar kehidupan; (2) terpenuhinya lapangan pekerjaan yang luas; (3) tumbuhnya pendapatan dan permintaan yang efektif; dan (4) meluasnya produksi dan perdagangan baik barang maupun jasa. Untuk mewujudkan tujuan tersebut maka perlu dibuat aturan yang saling menguntungkan melalui pengurangan tarif dan hambatan perdagangan lainnya serta penghapusan perlakuan diskriminatif dalam perdagangan internasional. ${ }^{1}$ Pada titik inilah WTO diidentikkan sebagai organisasi perdagangan internasional yang menganjurkan liberalisasi perdagangan barang dan jasa. Namun, hal yang perlu dicatat, menurut Bossche, adalah WTO juga mempertimbangkan pembangunan ekonomi yang berkelanjutan (sustainable) dan turut memperhatikan kebutuhan negara-negara berkembang. ${ }^{2}$

Secara garis besar, seperangkat aturan yang dibuat dalam WTO meliputi lima hal pokok, yaitu: (1) peraturan mengenai non-diskriminasi; (2) peraturan mengenai akses pasar; (3) peraturan mengenai perdagangan yang tidak adil; (4) peraturan mengenai hubungan antara liberalisasi perdagangan dan nilai-nilai serta kepentingan sosial lainnya; (5) peraturan mengenai harmonisasi perangkat hukum nasional dalam bidang-bidang khusus. ${ }^{3}$ Satu hal yang coba diatur dalam ketentuan WTO di atas adalah mengenai perdagangan yang tidak adil (unfair trade). Salah satu kebijakan negara yang dianggap sebagai praktik perdagangan tidak adil adalah subsidi. Subsidi merupakan salah satu perbuatan yang dikenal dalam konteks perdagangan internasional sebagai suatu perbuatan yang tidak adil karena dapat merugikan pihak-pihak yang terkena perbuatan praktik subsidi. ${ }^{4}$

Oleh karena dampak subsidi yang dapat menimbulkan rusaknya keseimbangan pasar maka WTO mengatur, baik secara umum maupun khusus, mengenai praktik subsidi tersebut. Secara umum, ketentuan tentang subsidi telah diatur dalam Pasal VI dan XVI General Agreement on Tariffs and Trade (GATT) 1994. Dalam kedua pasal tersebut persoalan subsidi belum dibahas secara spesifik. Berdasarkan alasan itu maka dibuatlah ketentuan khusus tentang subsidi, yaitu Agreement on Subsidies and Countervailing Measures (SCM Agreement) tahun 1994 yang merupakan perjanjian cakupan (covered agreement) dalam pembentukan WTO. Dengan adanya SCM tersebut maka pengaturan ihwal subsidi menjadi sangat ketat dan detil tidak seperti dalam ketentuan GATT.

Meskipun subsidi merupakan tindakan perdagangan yang tidak adil, namun pada prinsipnya subsidi dapat dilakukan secara terbatas menurut ketentuan WTO selama tidak menimbulkan efek yang dapat merugikan pihak lain. ${ }^{5}$ Pengecualian tersebut dilakukan karena subsidi lazim dilakukan oleh negara untuk meningkatkan kemakmuran dan melindungi kepentingan domestik. Salah satu isu subsidi yang sering dipermasalahkan antarnegara anggota WTO adalah perihal praktik subsidi di bidang perikanan dan produk-produk perikanan. ${ }^{6}$ Selisih pendapat tentang praktik subsidi di bidang perikanan disebabkan beberapa studi menyatakan bahwa adanya subsidi di bidang perikanan

Preambule, The Agreement Establishing the World Trade Organization, 1994.

Peter Van den Bossche, 2005, The Law and Policy of the World Trade Organization: Text, Cases and Materials, Cambridge University Press, UK, hlm. 86.

Peter van den Bossche, et al., 2010, Pengantar Hukum WTO, Yayasan Obor Indonesia, Jakarta, hlm. 3.

Christhophorus Barutu, 2007, Ketentuan Anti Dumping, Subsidi dan Tindakan Pengamanan (Safeguard) dalam GATT dan WTO, Citra Aditya Bakti, Bandung, hlm. 67.

Peter van den Bossche, Op.cit., hlm. 554.

Debashis Chakrabotry, et al., "Doha Round Negotiations on Subsidy and Countervailing Measures: Potential Implications on Trade Flows In Fishery Sector", Asian Journal of WTO \& International Health Law and Policy, Vol. 6, No. 1, Maret 2011, hlm. 203. 
menimbulkan penangkapan ikan yang berlebihan (overfishing). Akibat jangka panjangnya adalah stok ikan akan habis sehingga sumber daya perikanan tidak akan berkelanjutan. ${ }^{7}$

Indonesia, sebagai salah satu negara berkembang yang memiliki potensi perikanan dan produk perikanan cukup besar, memiliki kepentingan untuk tetap memberikan subsidi di bidang perikanan dan produk perikanan guna melindungi kepentingan nasional. Menurut Arif Satria, subsidi secara langsung, seperti skim kredit khusus bagi nelayan masih tetap diperlukan Indonesia untuk membantu kesejahteraan nelayan. Tentu saja hal tersebut juga perlu disertai dengan desain pengelolaan sumber daya perikanan. ${ }^{8}$ Oleh karena itu, Indonesia memprotes kebijakan dari WTO yang mengharuskan penghapusan subsidi dalam Konferensi Tingkat Menteri VI 2005 di Hongkong.

Berdasarkan latar belakang di atas, maka penulis tertarik untuk mengangkat permasalahan subsidi, khususnya subsidi di bidang perikanan, dalam WTO yang dikaitkan dengan kepentingan Indonesia. Adapun permasalahan yang coba diangkat dalam tulisan ini adalah: Pertama, bagaimana pengaturan subsidi perikanan dalam WTO? Kedua, bagaimanakah dampak pengaturan tersebut terhadap Indonesia?

\section{B. Pembahasan}

\section{Definisi dan Aturan Subsidi di WTO}

Belum ada kesepakatan diantara para pakar mengenai definisi subsidi. Hal ini terjadi karena terlampau luasnya tindakan-tindakan pemerintah yang dapat dianggap sebagai subsidi. Kesulitan ini diakui dalam laporan WTO tahun 2006 tentang Subsidi, Perdagangan dan WTO (Subsidies, Trade and The WTO). ${ }^{9}$ Dalam Black's Law Dictionary, ${ }^{10}$ subsidi diartikan sebagai, "A grant usually made by government, to any enterprise whose promotion is considered to be in public interest. Although government sometimes make direct payments subsidies usually indirect".

Sedangkan kamus Oxford, mendefinisikan subsidi sebagai " a sum of money granted from public funds to help an industry or business keep the price of a commodity or service low". ${ }^{11}$ Berdasarkan kedua pengertian subsidi tersebut di atas maka terdapat beberapa unsur dalam subsidi yakni: (1) adanya bantuan langsung maupun tidak langsung oleh pemerintah; (2) penerima subsidi adalah swasta atau perusahaan; (3) untuk tujuan kepentingan umum; harga barang dan jasa menjadi murah. Dalam hal perdagangan internasional, WTO kemudian membuat definisi subsidi agar terjadi keseragaman. Definisi subsidi secara otentik diatur dalam Agreement on Subsidies and Countervailing Measures (SCM) sebagai salah satu hasil putaran Uruguay. Pengaturan subsidi sebelumnya baik di GATT maupun Putaran Tokyo belum berhasil membuat definisi secara khusus mengenai subsidi.

Subsidi menurut SCM Pasal 1.1 butir a dan b adalah apabila adanya bantuan finansial dari pemerintah atau lembaga publik yang berada di wilayah negara anggota. Bentuk-bentuk bantuan finansial tersebut dibedakan menjadi empat, yaitu; (1) bantuan uang langsung; (2) insentif fiskal seperti potongan pajak; (3) bantuan penyediaan barang; atau jasa selain infrastruktur atau pembelian barang dan (4) membayarkan beban yang harus dibayar badan-badan privat. Praktik dalam beberapa kasus di WTO menyebutkan, untuk menentukan suatu negara melakukan subsidi atau tidak adalah telah memenuhi kedua elemen di bawah ini, yaitu: ${ }^{12}$

UNEP and WWF, 2009, Summary Report: The WTO Fishery Subsidies Negotiations: Update and Introductory Briefing for New Delegates, WTO, Jenewa, Paragraf 7 dan 8. Lihat juga Willian E. Schrank, 2003, Introducing Fisheries Subsidies: FAO Fisheries Technical Paper, FAO, Roma, hlm. 1.

Arif Satria, 2009, Ekologi Politik Nelayan, LKIS, Yogyakarta, hlm. 242.

WTO, 2006, Subsidies, Trade and the WTO, WTO, Jenewa, hlm. 47.

Bryan A. Garner, 2004, Black's Law Dictionary, Thomson \& West, St. Paul Min USA, hlm. 1469.

Ibid. Badan Sengketa WTO (DSB) sering menggunakan definisi dari Kamus Oxford untuk mengartikan istilah yang ada dalam perjanjian WTO. Contoh kasus adalah kata "payment" dalam sengketa Canada-Dairy.

WTO, 2007, WTO Analytical Index: Guide to WTO Law and Practice, Cambridge University Press, Cambridge, hlm. 752. 
yang pertama karena adanya bantuan finansial pemerintah (financial contribution) dan yang kedua adalah karena keuntungan (benefit). Pengertian bantuan finansial berdasarkan sejarah pembentukan SCM adalah bahwa tidak semua bantuan finansial pemerintah dapat memberikan keuntungan. Oleh karena itu, SCM membatasi bahwa elemen pertama subsidi yang harus dipenuhi adalah adanya bantuan finansial dari pemerintah atau badan publik.

Berdasarkan ketentuan Pasal 1 (1) (a) (i)-(iv) SCM membatasi apa yang dikategorikan sebagai bantuan finansial tersebut. Putusan Panel dalam kasus US-SoftWood Lumber III ${ }^{13}$ menyatakan bahwa bantuan finansial terjadi tidak saja adanya tindakan (act) atau pembiaran (omission) yang berkaitan dengan transfer uang, tetapi juga pada barang dan jasa yang dilakukan oleh pemerintah. Setelah elemen pertama berhasil ditemukan maka penentuan bantuan finansial pemerintah itu subsidi atau bukan ditentukan oleh elemen kedua yaitu adanya keuntungan yang diperoleh akibat bantuan tersebut.

Keuntungan (benefit) yang dimaksud dalam SCM adalah adanya manfaat (advantage) lebih yang diperoleh penerima bantuan finansial jika dibandingkan dengan kondisi pasar. ${ }^{14}$ Maksud keuntungan dari ketentuan tersebut lebih difokuskan kepada penerima bukan pemberi. Jadi, apabila dapat dibuktikan dengan adanya bantuan finansial pemerintah ternyata memberikan keuntungan kepada swasta maka hal tersebut sudah memenuhi unsur keuntungan. Tidak perlu dinilai pemerintah untung atau tidak. SCM juga mengatur tentang pembagian (penggolongan) subsidi, yaitu: subsidi yang dilarang (prohibition), subsidi yang dapat ditindak (Actionable Subsidies), subsidi yang tidak dapat ditindak (Non Actionable Subsidies). ${ }^{15}$

Subsidi yang dilarang menurut ketentuan SCM adalah subsidi ekspor dan subsidi domestik. Pengertian subsidi ekspor adalah subsidi diberikan untuk memberikan keuntungan kepada produsen untuk pasar luar negeri dengan memberikan keringanan-keringanan seperti pengenaan pajak ekspor yang rendah. Sedangkan subsidi domestik dimaksudkan memberikan bantuan finansial kepada produsen untuk pasar domestik sehingga harga jual bisa rendah dari harga produksi atau harga pasar. ${ }^{16}$

\section{Subsidi Perikanan dalam WTO}

Laporan dari lembaga Food and Agricultural Organization (FAO) menyatakan bahwa 50\% sumber daya perikanan telah dimanfaatkan secara maksimal, 25\% membutuhkan eksplorasi lebih lanjut sedangkan $25 \%$ lagi telah mengalami eksploitasi yang berlebihan dan membahayakan. ${ }^{17}$ Overfishing bahkan terus mengalami peningkatan sejak tahun $1990 .{ }^{18}$ Dengan kata lain, sumber daya perikanan pada saat ini telah sampai pada level membahayakan. Beberapa studi menyatakan bahwa penyebab utamanya dikarenakan adanya subsidi perikanan.

Subsidi perikanan adalah transfer finansial, langsung maupun tidak langsung, dari lembaga publik kepada sektor perikanan sehingga memberikan keuntungan lebih kepada sektor tersebut apabila hal itu tidak dilakukan. ${ }^{19}$ Sedangkan Food and Agricultural Organization of the United Nations (FAO) mendefinisikan subsidi perikanan sebagai "Government actions or inactions outside of normal practices that modify - by increasing or decreasing - the potential profits by the fisheries industry in the short-, medium- or long-term". ${ }^{20}$

Definisi subsidi perikanan menurut FAO

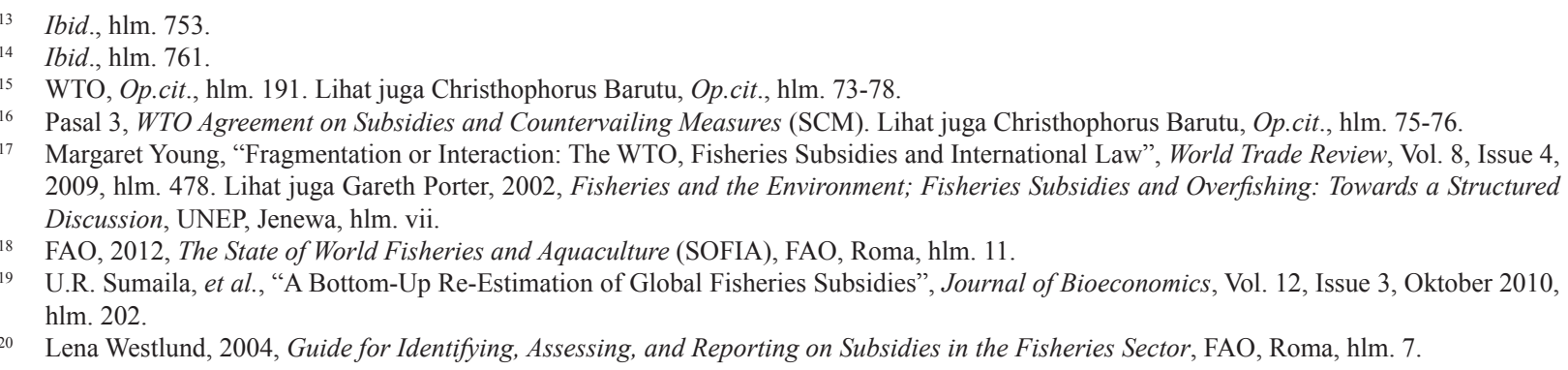


di atas menyatakan bahwa subsidi perikanan terjadi saat pemerintah melakukan atau tidak melakukan sesuatu di luar praktik pada umumnya untuk memodifikasi potensi keuntungan yang diperoleh industri perikanan. Pemerintah dalam definisi tersebut diartikan meluas yakni tidak hanya tindakan atau pembiaran badan pemerintah atau lembaga publik di bidang perikanan saja. Syaratnya adalah tindakan atau pembiaran tersebut memberikan keuntungan yang signifikan terhadap industri perikanan. ${ }^{21}$

Industri perikanan yang dimaksud dalam definisi FAO memiliki beberapa pengertian. Keseluruhan industri perikanan, mulai dari hulu sampai hilir, dimasukkan dalam definisi tersebut. Selain itu, pengertian di atas tidak hanya mengatur terkait dengan perikanan tangkap melainkan juga perikanan budidaya (aquaculture), industri besar dan kecil, untuk tujuan komersial maupun rekreasional. ${ }^{22}$ Dengan demikian, cakupan industri perikanan dalam definisi FAO sangat luas.

Pluralitas kategorisasi subsidi di bidang perikanan mendorong negara-negara untuk memasukkan pembahasan subsidi perikanan ke dalam rezim WTO. Pembahasan subsidi perikanan dalam WTO telah dimulai sejak awal $1996^{23}$ meskipun terdapat nada skeptis tentang korelasi antara perdagangan dengan lingkungan khususnya persoalan tentang subsidi perikanan, overfishing dan manajemen perikanan yang berkelanjutan. ${ }^{24}$

Sumaila $^{25}$ membagi subsidi sektor perikanan menjadi tiga, yaitu: (1) beneficial subsidies; (2) capacity-enhancing subsidies; (3) ambiguous subsidies. Subsidi yang menguntungkan (beneficial subsidies) merupakan program yang ditunjukkan sebagai investasi terhadap aset modal alami (natural capital). Dalam praktiknya subsidi jenis ini dilakukan untuk melakukan konservasi

Tabel 1. Perbandingan Kategorisasi Subsidi Perikanan ${ }^{26}$

\begin{tabular}{|c|c|c|c|}
\hline $\begin{array}{l}\text { Subsidi } \\
\text { Perikanan }\end{array}$ & FAO & APEC & OECD \\
\hline 1 & $\begin{array}{l}\text { Direct financial } \\
\text { transfer }\end{array}$ & $\begin{array}{l}\text { Direct assistance to fishers and } \\
\text { fisheries workers }\end{array}$ & Fisheries infrastructure \\
\hline 2 & $\begin{array}{l}\text { Services and indirect } \\
\text { financial transfer }\end{array}$ & Lending support programme & $\begin{array}{l}\text { Management, research, } \\
\text { enforcement and enhancement }\end{array}$ \\
\hline 3 & Regulations & $\begin{array}{l}\text { Tax preferences and insurance } \\
\text { support programmes }\end{array}$ & $\begin{array}{l}\text { access to other countries' } \\
\text { waters }\end{array}$ \\
\hline 4 & Lack of intervention & $\begin{array}{l}\text { Marketing and price support } \\
\text { programmes }\end{array}$ & $\begin{array}{l}\text { Decommissioning of vessels } \\
\text { and license retirement }\end{array}$ \\
\hline 5 & & $\begin{array}{l}\text { Fisheries management and } \\
\text { conservation programmes }\end{array}$ & investment and modernization \\
\hline 6 & & & $\begin{array}{l}\text { Income support and } \\
\text { employment insurance }\end{array}$ \\
\hline 7 & & & Taxation exemptions \\
\hline
\end{tabular}

Sumber: Gareth Porter, 2002.

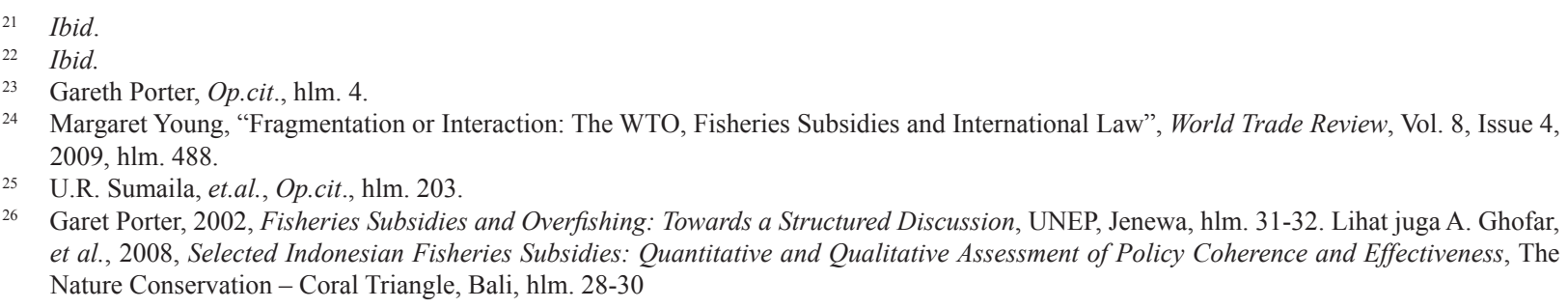

26 Garet Porter, 2002, Fisheries Subsidies and Overfishing: Towards a Structured Discussion, UNEP, Jenewa, hlm. 31-32. Lihat juga A. Ghofar, et al., 2008, Selected Indonesian Fisheries Subsidies: Quantitative and Qualitative Assessment of Policy Coherence and Effectiveness, The Nature Conservation - Coral Triangle, Bali, hlm. 28-30 
dan pengawasan terhadap tangkapan ikan ratarata. ${ }^{27}$ Subsidi peningkatan kapasitas (capacityenhancing) dimaksudkan sebagai subsidi yang malah memberikan disinvestasi, yakni dengan meningkatkan kapasitas perikanan malah akan menimbulkan over-exploitation sehingga keberlanjutan sumberdaya perikanan sulit terwujud. Salah satu jenis subsidi ini adalah subsidi bahan bakar. ${ }^{28}$ Subsidi ambigu adalah program bantuan yang belum diketahui (ambigu) hasil akhirnya, apakah berupa investasi atau disinvestasi. Contoh subsidi jenis ini adalah bantuan (asistensi) program perikanan seperti penyuluhan perikanan. ${ }^{29}$

Praktik penggunaan ketiga subsidi di atas memiliki dampak terhadap keuntungan dari perusahaan-perusahaan yang bergerak di bidang perikanan. ${ }^{30}$ Keuntungan tersebut diperoleh karena dengan adanya subsidi perikanan maka pendapatan mereka akan meningkat sedangkan biaya (cost) semakin mengecil. Terdapat perbandingan yang cukup dinamis perihal penggunaan subsidi perikanan secara global antara negara maju dengan negara berkembang. Tiap-tiap jenis subsidi digunakan oleh masing-masing negara untuk meningkatkan keuntungan yang diperoleh dari bidang perikanan. Data yang dikumpulkan Sumaila menunjukkan, misalnya bahwa negara maju memberikan subsidi yang besar di bidang manajemen perikanan dibandingkan negara berkembang. Sedangkan negara berkembang memberikan subsidi yang besar perihal bantuan pembuatan bahan bakar dan perbaikan kapal.

Tabel 2. Estimasi Subsidi Perikanan secara Global

\begin{tabular}{|c|c|c|c|c|}
\hline Fishery Subsidy Type & $\begin{array}{l}\text { Developing } \\
\text { Countries }\end{array}$ & $\begin{array}{l}\text { Developed } \\
\text { Countries }\end{array}$ & $\begin{array}{c}\text { Global } \\
\text { total }\end{array}$ & $\%$ \\
\hline \multicolumn{5}{|l|}{ Beneficial } \\
\hline Fisheries management & 1.69 & 3.5 & 5.19 & 19 \\
\hline Fishery $R \& D$ & 0.90 & 0.93 & 1.83 & 7 \\
\hline MPAs & 0.19 & 0.73 & 0.92 & 3 \\
\hline Capacity-Enhancing & & & & \\
\hline $\begin{array}{l}\text { Boat Construction and } \\
\text { Renovation }\end{array}$ & 2.14 & 0.73 & 0.92 & 11 \\
\hline $\begin{array}{l}\text { Fisheries Development } \\
\text { Projects }\end{array}$ & 0.43 & 0.36 & 0.78 & 3 \\
\hline Fishing port development & 0.31 & 2.52 & 2.83 & 10 \\
\hline $\begin{array}{l}\text { Marketing and storage } \\
\text { infrastructure }\end{array}$ & 0.76 & 0.63 & 1.39 & 5 \\
\hline Tax exemption & 0.64 & 0.36 & 1.00 & 4 \\
\hline Fishing access & 0.00 & 1.00 & 1.00 & 4 \\
\hline Fuel Subsidies & 1.48 & 4.88 & 6.36 & 23 \\
\hline Ambiguous & & & & \\
\hline Fisher Assistance & 0.03 & 1.35 & 1.39 & 5 \\
\hline Vessel Buyback & 0.00 & 1.44 & 1.44 & 5 \\
\hline Rural Fisher Communities & 0.20 & 0.00 & 0.20 & 1 \\
\hline Total & 8.75 & 18.44 & 27.20 & 100 \\
\hline
\end{tabular}

Sumber: ICES Journal of Marine Science, 2013.

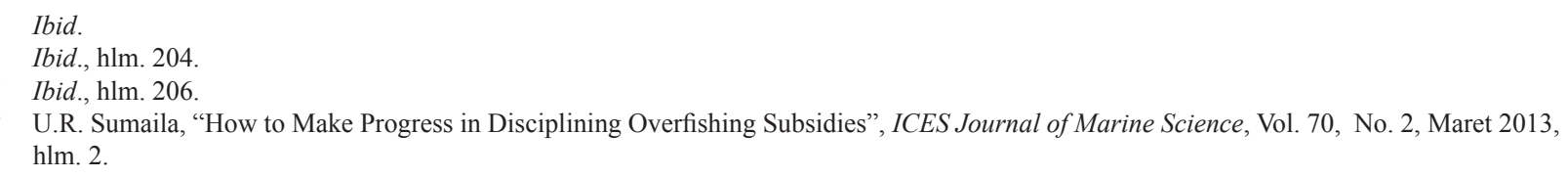


Dalam WTO, belum ada ketentuan khusus yang mengatur tentang subsidi di bidang perikanan. Perikanan dan produknya menjadi isu yang dibahas dalam Non Agricultural Market Access (NAMA) yang spesifik berbicara soal pengurangan tarif dan tidak meliputi pembahasan soal subsidi perikanan. ${ }^{31}$ Dengan demikian, oleh karena isu perikanan dan produknya dikeluarkan dari isu agrikultur pada putaran Uruguay tahun 1993 dan masuk dalam NAMA maka ketentuan WTO yang dapat digunakan perihal subsidi perikanan adalah SCM. ${ }^{32}$ Meskipun demikian, tidak ada kesepakatan antara anggota WTO bahwa SCM dapat digunakan untuk mengatur tentang subsidi perikanan. Akhirnya, negara-negara sepakat untuk membuat pembahasan khusus tentang subsidi perikanan. ${ }^{33}$ WTO kemudian secara lebih lanjut mencoba untuk memodifikasi dan mengatur ketentuan mengenai subsidi yang terdapat dalam SCM untuk mengatasi persoalan overfishing dan overcapacity di bidang perikanan. ${ }^{34}$

Subsidi perikanan dibahas secara serius dalam Deklarasi Doha 2001 yang menyepakati bahwa regulasi tentang subsidi perikanan akan diperjelas dan ditingkatkan. Kesepakatan tersebut kemudian dibahas lebih lanjut dalam Konferensi Tingkat Menteri (KTM) di Hongkong tahun 2005. Pada pertemuan itu disebutkan bahwa larangan terhadap subsidi perikanan yang menimbulkan overfishing dan overcapacity. Selain itu, persoalan perlakuan khusus dan berbeda (S\&D) termasuk isu yang harus diatur dalam subsidi perikanan. ${ }^{35}$ Perkembangan negosiasi dalam pembahasan subsidi perikanan dalam WTO hingga saat ini adalah draft (revisi) yang dibuat oleh group of rules pada akhir 2008. Rencananya rancangan regulasi tersebut akan dijadikan Annex VIII perjanjian SCM. ${ }^{36}$

Dalam pembahasan subsidi perikanan terdapat dua model pendekatan, yaitu pendekatan dari atas ke bawah (top-down) dan pendekatan dari bawah ke atas (bottom-up). Pendekatan dari atas ke bawah mengatur bahwa pada dasarnya semua subsidi perikanan dilarang. Hanya subsidi perikanan yang diperbolehkan saja kemudian dibuat daftarnya (list). Sedangkan pendekatan dari bawah ke atas mengatur sebaliknya. Pada dasarnya semua subsidi perikanan boleh, jadi regulasi tentang subsidi perikanan hanya yang dilarang saja. ${ }^{37}$

Rancangan regulasi tentang subsidi perikanan terdiri dari delapan pasal. ${ }^{38}$ Pasal 1 mengatur tentang klasifikasi subsidi perikanan yang dilarang. Larangan tersebut tidak berlaku atas least-developed country (LDC) sebagai bagian dari perlakuan khusus dan berbeda (S\&D). ${ }^{39}$ Pasal 2 dan 5 draft subsidi perikanan mengatur tentang pengecualian-pengecualian terhadap larangan subsidi perikanan. Pengecualian-pengecualian tersebut dapat dibenarkan untuk subsidi yang tidak terkait dengan pembuatan kapal baru, subsidi yang tidak memberikan peningkatan tangkapan ikan, subsidi untuk standar keselamatan serta manajemen perikanan.

Pasal 4 mengatur tentang penggunaan subsidi perikanan secara umum. Pada prinsipnya, setiap negara dilarang untuk menggunakan subsidi yang larang oleh Pasal 1 yang dapat membahayakan perikanan dan penangkapan ikan berlebihan (over capacity) atas persediaan ikan yang melakukan migrasi ke wilayah ZEE negara lain (straddling stock) serta spesies ikan yang melakukan migrasi jauh. Untuk pelaksanaan draft regulasi subsidi

\footnotetext{
31 Yagi Nobuyaki, "Living Marine Resources in the Doha Round of WTO Trade Talks", www.rieti.go.jp/en/events/bbl/08092107.html, diakses 28 Januari 2014.

32 Kemi Lewis, "Fisheries Subsidies and the WTO: An EU Perspective", CEPMLP Annual Review, Vol. 7, 2003 , hlm. 5.

Ibid., hlm. 14.

34 Michael Sheng-ti GAU, "ASIA Perspectives on Fisheries Subsidy Issues and Linkages with Environment”, Asian Journal of WTO \& International Health Law and Policy, Vol. 1, No. 1, Maret 2006, hlm. 194

35 WTO Ministerial Declaration, "DOHA Work Programme: Annex D on Anti Dumping and Subsidies and Countervailing Measures Including Fisheries Subsidies", http://www.wto.org/english/thewto e/minist e/min05 e/final annex e.htm, diakses 20 Januari 2014.

Jinji Naoto, 2010, Subsidies, Fisheries Management and International Trade, RIETI, Tokyo, hlm. 4.

Ibid.

38 WTO Negotiating Group on Rules, "Draft Consolidated Chair Texts of the Ad and SCM Agreements: Annex VIII", http://www.wto.org/.../ rules_chair text nov07_e.doc, diakses 20 Januari 2014.

39 Ibid., Pasal 3.
} 
di bidang perikanan tersebut, setiap negara wajib melakukan pemberitahuan (notification) dan pengawasan (surveillance) kepada komite perdagangan dan lingkungan WTO. ${ }^{40}$

Pasal $7^{41}$ mengatur tentang masa transisi. Apabila ketentuan subsidi negara anggota telah ada sebelum regulasi berlaku (entry into force) maka negara tersebut wajib memberitahukan kepada komite. Jangka waktu yang diberikan adalah 90 hari untuk negara maju dan 180 hari untuk negara berkembang. Setelah pemberitahuan tersebut, diberikan jangka waktu 2 (dua) tahun untuk negara maju agar menyesuaikan ketentuan subsidi perikanannya. Sedangkan negara berkembang diberikan jangka waktu 4 (empat) tahun untuk melakukan harmonisasi.

Proses penyelesaian sengketa atas subsidi perikanan telah diatur dalam Pasal $8 .{ }^{42}$ Hal yang menarik adalah bahwa dalam sengketa yang terkait dengan persoalan teknis dan ilmiah, maka panel dapat meminta pendapat (advice) dari ahli perikanan yang telah dipilih panel dalam proses konsultasi. Dalam Pasal 8 ayat (5) juga diatur bahwa mekanisme penyelesaian sengketa yang dapat digunakan tidak terbatas yang ada dalam DSU WTO, namun dapat juga menggunakan jasa baik atau mekanisme penyelesaian sengketa yang terdapat dalam organisasi internasional atau perjanjian internasional.

\section{Subsidi Perikanan di Indonesia}

Indonesia memiliki luas total 5,8 juta $\mathrm{km}^{2}$ wilayah perairan yang terdiri dari Zona Ekonomi Eksklusif seluas 2,7 juta $\mathrm{km}^{2}$, perairan kepulauan 2,8 juta $\mathrm{km}^{2}$ dan wilayah laut 0,3 juta $\mathrm{km}^{2} .{ }^{43}$ Dengan luas wilayah perairan sebesar $3 / 4$ dari total wilayah Indonesia, perikanan harusnya dapat menjadi komoditas yang bisa diandalkan sebagai pendapatan negara. Akan tetapi nyatanya sumbangan bidang perikanan terhadap pendapatan domestik bruto (PDB) pada tahun 2011 hanya sebesar Rp227,76 triliun atau sekitar 3,07\% dari PDB total nasional. Jumlah tersebut menurun dari pendapatan yang diperoleh pada tahun 2010 yakni sebesar Rp299,22 triliun atau sekitar 3,10\% dari PDB total nasional. ${ }^{44}$ Produksi perikanan pada tahun 2011 mencapai 12,39 juta ton, terdiri dari produksi perikanan tangkap sebesar 5,41 juta ton dan perikanan budidaya sebesar 6,85 juta ton. ${ }^{45}$ Data tersebut menempatkan

Tabel 3. Volume Produksi Perikanan 2007-2011

\begin{tabular}{|c|c|c|c|c|c|c|c|}
\hline \multirow{2}{*}{ Rincian } & \multicolumn{5}{|c|}{ Tahun } & \multicolumn{2}{|c|}{$\begin{array}{c}\text { Kenaikan } \\
\text { Rata-Rata (\%) }\end{array}$} \\
\hline & 2007 & 2008 & 2009 & 2010 & 2011*) & $\begin{array}{r}2007- \\
2011\end{array}$ & $\begin{array}{r}2010- \\
2011\end{array}$ \\
\hline Perikanan Tangkap & 5.044 .737 & 5.003 .115 & 5.107 .971 & 5.348 .740 & 5.409 .100 & 35,71 & 0,46 \\
\hline Perikanan Laut & 4.734 & 4.701 .933 & 4.812.2 & 5.05 & 5.0 & 35,61 & 0,44 \\
\hline Perikanan Umum & 310.457 & 301.182 & & 326. & & 37,52 & 0,71 \\
\hline Perirkanan Budidaya & 3.193 .565 & 3.855 .200 & 4.708 .563 & 5.478 .062 & 6.976 .750 & 62,44 & 11,13 \\
\hline Budidaya Laut & 1.509 .528 & 1.966 .002 & 2.820 .083 & 3.385 .552 & 3.735. & 68,20 & 6,28 \\
\hline Tambak & 933.833 & 959.509 & 907.123 & 990.403 & 1.734 .260 & 58,62 & 22,47 \\
\hline Kolam & 410.373 & 479.167 & 554.067 & 627.643 & 955.511 & 65,64 & 16,55 \\
\hline Karamba & 63.929 & 75.769 & 101.771 & 117.860 & 120.645 & 57,16 & 0,51 \\
\hline Jaring Apung & 190.893 & 263.169 & 238.606 & 272.705 & 331.936 & 55,16 & 7,25 \\
\hline Sawah & 85.009 & 111.584 & 86.913 & 83.900 & 98.804 & 40,48 & 2,28 \\
\hline Volume Produ & 8.238.302 & 8.858 .315 & 9.816 .534 & 10.835 .610 & 12.385 .850 & 47,78 & 6,20 \\
\hline
\end{tabular}

Sumber: Laporan Akuntabilitas Kinerja Kementerian Kelautan dan Perikanan Tahun 2011.

Ruchyat Deni Dj., 2009, Bahari Nusantara untuk Kesejahteraan Masyarakat dan Ketahanan Nasional, MSCC, Jakarta, hlm. 3.

44 Kementerian Kelautan dan Perikanan, 2012, Laporan Akuntabilitas Kinerja Kementerian Kelautan dan Perikanan Tahun 2011, Kementerian Kelautan dan Perikanan, Jakarta, hlm. vii.

45 Ibid., hlm. 18. 
Indonesia sebagai negara produsen perikanan terbesar ketiga di dunia setelah China dan Peru. ${ }^{46}$

Pada level konsumsi, produksi perikanan Indonesia masih harus bersaing dengan produk perikanan impor. Data Badan Pusat Statistik tahun 2011 menunjukkan nilai impor ikan dan produk perikanan pada Januari-Februari 2011 sebesar USD71,12 juta atau melonjak dibandingkan periode yang sama di $2010^{47}$ Korban dari adanya produk perikanan impor tersebut adalah nasib nelayan. Dengan peralatan yang sederhana dan modal terbatas, nelayan kecil akan sulit untuk bersaing dengan pengusaha di bidang perikanan. Data dari Direktorat Jenderal Perikanan Tangkap tahun 2011, jumlah nelayan dalam periode tahun 2001-2011 mengalami penurunan rata-rata sebesar $0,99 \%$ per tahun, yaitu dari 3.286 .500 orang pada tahun 2001 menjadi 2.755 .178 orang pada tahun 2011. ${ }^{48}$ Apabila nelayan kecil tidak dilindungi oleh pemerintah melalui program bantuan maka akan banyak nelayan yang akan berpindah profesi.

Bantuan pemerintah di bidang perikanan, khususnya perikanan tangkap, untuk meningkatkan produksi tentu saja harus juga memperhatikan manajemen perikanan yang berkelanjutan. Bantuan pemerintah di bidang perikanan inilah yang bisa dikategorikan sebagai subsidi bidang perikanan. Salah satu contoh fasilitasi pemerintah adalah kegiatan fasilitasi penguatan dan pengembangan pemasaran luar negeri dalam rangka mendukung kinerja ekspor hasil perikanan. Selain bentuk subsidi di atas, Pemerintah juga melakukan beberapa jenis subsidi perikanan. A. Ghofar, membuat klasifikasi subsidi bidang perikanan yang dilakukan oleh Indonesia beserta resiko terjadinya kelebihan tangkap, yaitu: ${ }^{49}$
Tabel 4. Jenis Subsidi dan Tingkat Resiko

\begin{tabular}{|c|c|c|c|}
\hline No. & Bentuk Subsidi & $\begin{array}{c}\text { Jenis } \\
\text { Resiko }\end{array}$ & $\begin{array}{l}\text { Tingkat } \\
\text { Resiko }\end{array}$ \\
\hline \multirow[t]{2}{*}{1.} & Pengadaan dan & Negatif & Sangat \\
\hline & $\begin{array}{l}\text { Modernisasi kapal dan } \\
\text { alat tangkap }\end{array}$ & & Tinggi \\
\hline 2. & $\begin{array}{l}\text { Penyediaan biaya } \\
\text { operasional }\end{array}$ & Negatif & $\begin{array}{l}\text { Sangat } \\
\text { Tinggi }\end{array}$ \\
\hline 3. & $\begin{array}{l}\text { Penyediaan akses } \\
\text { terhadap modal }\end{array}$ & Negatif & Tinggi \\
\hline 4. & Pengadaan infrastruktur & Negatif & Sedang \\
\hline 5. & $\begin{array}{l}\text { Bantuan pemasaran dan } \\
\text { promosi }\end{array}$ & Negatif & Sedang \\
\hline 6. & $\begin{array}{l}\text { Introduksi keterampilan } \\
\text { dalam teknik } \\
\text { penangkapan ikan }\end{array}$ & Negatif & Sedang \\
\hline 7. & Bantuan sosial lainnya & Negatif & Sedang \\
\hline 8. & $\begin{array}{l}\text { Introduksi keterampilan } \\
\text { dalam memberi nilai } \\
\text { tambah produk dan } \\
\text { keterampilan tambahan } \\
\text { lainnya }\end{array}$ & Negatif & Rendah \\
\hline & $\begin{array}{l}\text { Introduksi keterampilan } \\
\text { dalam manajemen } \\
\text { sumber daya perikanan } \\
\text { dan konservasi }\end{array}$ & Positif & \\
\hline
\end{tabular}

Sumber: A. Ghofar, et al., 2008.

Pengaturan tentang subsidi perikanan juga terdapat dalam UU Nomor 31 Tahun 2004 tentang Perikanan jo. UU Nomor 45 Tahun 2009 tentang Perubahan Atas UU Nomor 31 Tahun 2004 tentang Perikanan. Pasal 48 ayat 2 UU Nomor 31 Tahun 2004 misalnya menyebutkan bahwa pungutan perikanan tidak dikenakan bagi nelayan kecil dan pembudi daya ikan kecil. Selain itu, Bab IX (Pasal 57-59) UU yang sama mengatur tentang subsidi dengan memberikan bantuan pendidikan, pelatihan dan penyuluhan perikanan. Sedangkan Bab X (Pasal 60-64) mengatur tentang bantuan melalui pemberdayaan nelayan kecil dan pembudi daya ikan kecil. Belum lagi regulasi di bidang yang tidak terkait khusus dengan perikanan, misalnya pemberian subsidi BBM untuk nelayan. 
Beragam subsidi tersebut memang tidak bisa dihindarkan karena tujuan pemberian subsidi tersebut adalah untuk kepentingan nasional dalam hal ini pengelolaan perikanan. Akan tetapi perlu diingat bahwa adanya subsidi perikanan harus sesuai dengan asas-asas pengelolaan perikanan yang diatur dalam Pasal 2 UU Nomor 45 Tahun 2009 tentang Perubahan Atas UU Nomor 31 Tahun 2004 tentang Perikanan yang terdiri dari: (a) manfaat; (b) keadilan; (c) kebersamaan; (d) kemitraan; (e) kemandirian; (f) pemerataan; (g) keterpaduan; (h) keterbukaan; (i)efisiensi; (j) kelestarian; dan (k) pembangunan yang berkelanjutan.

Isu yang sering diangkat dalam subsidi perikanan biasanya mengenai akses pasar dan sumberdaya. Padahal selain pendekatan di atas, subsidi perikanan harus juga melihat sisi dari ketenagakerjaan. ${ }^{50}$ Dengan demikian, saat membicarakan masalah perikanan maka tidak bisa menghilangkan faktor nelayan (pekerja) yang bergantung hidup pada mata pencaharian mencari ikan. Apabila subsidi dihilangkan, maka nelayannelayan tradisional yang masih banyak terdapat di negara-negara berkembang akan tergerus oleh nelayan negara maju yang telah menggunakan peralatan modern.

Praktik tersebut telah terjadi di sebagian besar negara di kawasan Afrika. Uni Eropa (UE) misalnya telah membuat 20 (dua puluh) perjanjian perikanan dengan negara-negara di Afrika untuk mengizinkan kapal-kapal ikan dari negara anggota UE untuk menangkap ikan di kawasan ZEE negara tersebut. ${ }^{51}$ Dengan memahami tiga isu pokok dalam subsidi perikanan, maka persoalannya tidak sesederhana hanya memilih antara menolak atau memberlakukan subsidi. Sebab terjadinya overfishing dan overcapacity bisa jadi tidak hanya karena faktor tunggal yaitu subsidi. Akan tetapi perlu juga diperhatikan mengenai pengelolaan sumber daya perikanan. ${ }^{52}$

\section{Subsidi Perikanan di WTO dan Dampaknya bagi Indonesia}

Fokus program pemerintah di bidang perikanan diarahkan untuk pencapaian 3 (tiga) indikator sasaran utama. Pertama, pro poor yakni meningkatkan pendapatan nelayan, pembudidaya ikan dan masyarakat pesisir menjadi sebesar $\mathrm{Rp}$ 1,5 juta per orang per bulan, dan meningkatnya jangkauan program pemberdayaan masyarakat sebesar $16 \%$ (850.000 orang) dari populasi masyarakat pesisir yang miskin, termasuk pemberdayaan perempuan sebanyak 350.000 orang. Kedua, pro job yakni meningkatnya penyerapan tenaga kerja kelautan dan perikanan menjadi 10,02 juta orang. Ketiga, pro growth yakni meningkatnya kontribusi PDB perikanan terhadap PDB nasional non migas (tidak termasuk pengolahan) menjadi $5,00 \%{ }^{53}$

Untuk memenuhi ketiga fokus program pemerintah di bidang perikanan tersebut pemerintah melakukan beberapa tindakan subsidi. Setidaknya menurut A. Ghofar, ${ }^{54}$ pemerintah Indonesia telah melakukan 9 (sembilan) bentuk subsidi dimana 8 (delapan) diantaranya menimbulkan resiko negatif yaitu terjadinya penangkapan ikan secara berlebihan. Padahal sesuai dengan asas pengelolaan perikanan, tindakan subsidi tersebut tidak boleh menimbulkan pengelolaan ikan yang tidak berkelanjutan.

Bentuk-bentuk subsidi yang dilakukan pemerintah merupakan subsidi yang dilarang dalam draft WTO tentang subsidi perikanan. Apabila ketentuan tersebut berhasil disepakati oleh negara anggota WTO maka pengelolaan perikanan Indonesia akan mengalami dampak

\footnotetext{
Arif Satria, 2009, Ekologi Politik Nelayan, LKIS, Yogyakarta, hlm. 242.

Margaret A. Young, "Fragmentation or Interaction: the WTO, Fisheries Subsidies and International Law", World Trade Review, Vol. 8, Issue 4, Desember 2009, hlm. 482.

3 Soen'an Hadi Purnomo, “DKP Tingkatkan Daya Saing Sektor Kelautan dan Perikanan untuk Kesejahteraan Masyarakat”, http://www.antara. co.id/arc/2009/2/.../dkp-tingkatkan-daya-saing-sektor-kelautan-dan-perikanan-untuk-kesejahteraan-masyara... - $23 k$, diakses 21 Januari 2014.

${ }^{54}$ Zainal A. Muchlisin dkk., “Analisis Subsidi Perikanan Non BBM di Kabupaten Aceh Besar, Provinsi Nanggroe Aceh Darussalam”, Jurnal Depik, Vol. 1, No. 3, Desember 2012, hlm.173.
} 
yang buruk khususnya terkait dengan pengelolaan pasar perikanan, sumber daya perikanan serta lapangan pekerjaan. Di bidang pasar perikanan, pemberlakuan subsidi perikanan WTO akan menurunkan produksi perikanan tangkap. Hal ini dikarenakan kapal ikan yang beroperasi rata-rata merupakan perahu motor tempel. Sedangkan untuk kapal yang memiliki kapasitas tangkap sekitar 3050 GT hanya berjumlah $19,01 \%$ dari keseluruhan total kapal ikan di Indonesia. ${ }^{55}$ Apabila pemerintah tidak memberikan perlindungan (regulasi) terhadap kapal ikan yang berkapasitas tangkap kecil maka dapat dipastikan bahwa produksi perikanan tangkap di laut akan menurun drastis.

Dimasukannya bantuan modernisasi kapal ikan serta fasilitas pembuatan kapal ikan baru sebagai bagian dari subsidi perikanan dalam WTO akan berpengaruh sangat besar terhadap kemampuan produksi perikanan tangkap. Padahal kapal-kapal ikan yang digunakan oleh nelayan Indonesia termasuk kapal ikan lama yang secara teknologi sudah ketinggalan zaman dan kemampuan tangkap yang kecil. Regulasi tentang bantuan harga (price support) bagi produksi perikanan untuk tujuan ekspor juga dikategorikan sebagai subsidi perikanan oleh WTO. Dengan tidak adanya skema tersebut maka harga produk perikanan Indonesia akan sulit untuk bersaing dengan produk perikanan dari negara maju. Kesulitan tersebut terjadi karena pengelolaan produk perikanan Indonesia yang tidak efisien. Nilai efisiensi sudah tentu berdampak pada harga produksi perikanan. Dengan demikian harga produk perikanan dapat dipastikan akan lebih mahal jika dibandingkan produk perikanan dari negara maju yang dikelola secara efisien.

Selain itu, pemerintah juga harus menjamin ketersediaanprodukperikananuntukkonsumsidalam negeri. Subsidi harga untuk tujuan ekspor idealnya dilakukan ketika ketersediaan untuk konsumsi di dalam negeri sudah terpenuhi. Jangan sampai upaya untuk menggenjot nilai ekspor produk perikanan melalui subsidi ekspor membuat ketersediaan konsumsi berkurang sehingga membuka keran impor untuk produk perikanan semakin besar. Hal yang sama bisa juga terjadi di bidang produksi perikanan budidaya. Program Pengembangan Usaha Masyarakat Pedesaan (PUMP) Perikanan Budidaya $^{56}$ harus dihentikan apabila draft subsidi perikanan WTO jadi diberlakukan. Padahal bantuan sosial PUMP merupakan upaya pemerintah untuk meningkatkan produksi perikanan budidaya. Dengan produksi perikanan budidaya yang terjadi maka ketersediaan konsumsi ikan untuk pasar dalam negeri akan terpenuhi sehingga tidak perlu dilakukan impor produk perikanan. Bahkan data BPS mencatat, sebelum adanya larangan subsidi perikanan oleh WTO, produk ikan impor dari China sudah meningkat peredarannya di pasar.

Di tingkat pengelolaan hasil perikanan, produksi Indonesia juga pasti akan terkena dampak, hal ini disebabkan karena pembangunan infrastruktur untuk industrialisasi di bidang perikanan masih dilakukan oleh pemerintah. Khususnya tentang fasilitas pendaratan ikan di pelabuhan-pelabuhan. Masalahnya adalah draft subsidi perikanan di WTO melarang subsidi infrastruktur termasuk pelabuhan apabila hal itu terkait dalam aktifitas penangkapan ikan. Jika demikian yang terjadi maka produk pengelolaan ikan dari luar negeri akan masuk Indonesia dan secara perlahan namun pasti akan membunuh industri pengelolaan perikanan lokal.

Pada sisi sumber daya perikanan, dengan adanya larangan subsidi perikanan WTO bisa menimbulkan under capacity pengelolaan perikanan Indonesia. Hal tersebut dapat terjadi karena potensi perikanan yang berada di wilayah perairan Indonesia yang sangat luas tidak akan mampu dikelola tanpa ada campur tangan pemerintah. Bantuan pemerintah tersebut sangat dibutuhkan khususnya di bidang infrastruktur perikanan seperti pelabuhan, tempat 
pelelangan ikan dan modernisasi kapal ikan.

Apabila hal itu terjadi maka peluang masuknya kekuatan modal asing di bidang perikanan untuk mengelola sumber daya perikanan Indonesia semakin terbuka luas. Masuknya investasi asing untuk mengelola sumber daya perikanan bukanlah terlarang sama sekali. Akan tetapi apabila tidak dibarengi dengan penguatan kapasitas industri perikanan di dalam negeri maka Indonesia hanya akan jadi penonton di negeri sendiri. Beragam bentuk subsidi perikanan yang dilakukan Indonesia tentu saja juga harus memperhatikan keberlanjutan sumber daya perikanan. Pada titik inilah maka manajemen sumber daya perikanan menjadi sangat penting. Untuk itu data tentang ketersediaan ikanikan jenis tertentu perlu dibuat secara berkala. Dengan data tersebut maka kebijakan penangkapan ikan bisa di rekayasa agar spesies-spesies ikan tertentu tidak mengalami kepunahan.

Selain memberikan subsidi perikanan, pemerintah juga perlu melakukan pengawasan tentang penggunaan subsidi terkait sumber daya perikanan. Jangan sampai subsidi perikanan malah digunakan untuk membeli alat produksi yang malah membahayakan keberlanjutan sumber daya perikanan. Jadi, pemerintah tidak bisa lepas tangan hanya sekedar memberikan bantuan kepada masyarakat namun juga berkewajiban untuk melakukan pengawasan atas penggunaannya. Di bidang lapangan pekerjaan, larangan subsidi perikanan yang terdapat dalam draft WTO akan membuat nelayan kehilangan pekerjaan. Larangan dukungan pendapatan (income support) kepada nelayan akan membuat pendapatan mereka tidak mencukupi kebutuhan hidup. Sebab sebagian besar nelayan Indonesia tidak memiliki modal cukup. Jika skema kredit khusus nelayan dicabut karena merupakan subsidi yang dilarang menurut WTO maka nelayan akan mengalami kesulitan untuk melaut.

Bantuan-bantuan pemerintah lainnya seperti fasilitas pembebasan pajak dan retribusi perikanan bagi nelayan kecil sangat membantu daya hidup mereka. Namun, sejak hal tersebut dijadikan kategori subsidi yang terlarang dalam draft subsidi perikanan di WTO maka pemerintah tidak bisa lagi melakukan hal tersebut. Pembebasan pajak dan retribusi bagi nelayan kecil sesungguhnya akan mengurangi ongkos produksi sehingga akan menaikkan nilai pendapatan mereka. Selain itu, harga jual produk perikanan mereka juga akan kompetitif di pasar.

Pemberian bantuan bahan bakar minyak (BBM) kepada nelayan kecil merupakan subsidi yang dilarang dalam draft subsidi perikanan WTO. Padahal biaya tingginya harga BBM akan mengurangi pendapatan mereka. Sebab biaya untuk bahan bakar dalam proses penangkapan ikan memiliki porsi yang cukup besar. Jika nelayan kecil tidak dilindungi dengan subsidi BBM maka akan banyak nelayan yang tidak akan bisa menghidupkan kapalnya. Belum lagi bentuk larangan subsidi lain yang terkait dalam proses produksi perikanan, seperti subsidi persediaan es batu untuk pengawetan ikan. Apabila ketentuan dalam draft subsidi perikanan WTO diberlakukan maka akan banyak nelayan kecil yang berpindah profesi.

Selain pemberian beragam bentuk subsidi perikanan, persoalan pengawasan pemerintah atas penggunaan subsidi tersebut juga harus ditingkatkan. Jangan sampai adanya subsidi tersebut malah digunakan oleh free rider untuk memperoleh keuntungan ganda. Oleh karena itu, perlindungan terhadap nelayan-nelayan kecil harus diutamakan. Dalam pemberian subsidi terhadap nelayan-nelayan kecil, juga perlu dibarengi dengan penguatan kapasitas kemampuan mereka dalam mengelola produksi perikanan. Pengelolaan tersebut mulai dari persiapan hingga pemasaran hasil produk perikanan. Bentuk yang dapat dilakukan oleh pemerintah adalah melalui penyuluhan-penyuluhan kepada para nelayan tersebut.

\section{Penutup}

Berdasarkan pembahasan di atas, maka dapat ditarik simpulan sebagai berikut: Pertama, aturan 
subsidi perikanan di WTO belum diatur dalam ketentuan yang spesifik. Pembahasan hingga saat ini masih berupa draft subsidi perikanan yang akan dimasukkan sebagai Annex VIII Agreement on Subsidies and Countervailing Measures (SCM). Dalam draft tersebut diatur tentang larangan subsidi perikanan, beberapa pengecualian terhadap larangan subsidi, manajemen perikanan, perlakuan khusus dan berbeda terhadap leastdeveloped country (LDC), mekanisme penyelesaian sengketa. Kedua, dampak draft WTO tentang subsidi perikanan terhadap Indonesia apabila berhasil disepakati akan berdampak negatif terhadap tiga hal yaitu pasar perikanan, sumber daya perikanan dan lapangan pekerjaan bidang perikanan. Adapun saran yang dapat diberikan adalah: Pertama, mendorong pemerintah untuk melakukan negosiasi terhadap draft subsidi perikanan WTO tersebut yang disesuaikan dengan kepentingan nasional kita. Dasar negosiasi yang bisa digunakan adalah untuk melindungi pasar perikanan, sumber daya perikanan dan lapangan pekerjaan. Kedua, pemberian subsidi perikanan harus terus dilaksanakan pemerintah khususnya untuk melindungi nelayan dan industri perikanan kecil. Namun selain itu, pengawasan atas penggunaan subsidi perikanan harus dilakukan secara ketat.

\section{DAFTAR PUSTAKA}

\section{A. Buku}

Barutu, Christhophorus, 2007, Ketentuan Anti Dumping, Subsidi dan Tindakan Pengamanan (Safeguard) dalam GATT dan WTO, Citra Aditya Bakti, Bandung.

Deni Dj, Ruchyat, 2009, Bahari Nusantara Untuk Kesejahteraan Masyarakat dan Ketahanan Nasional, MSCC, Jakarta.

Direktorat Jenderal Perikanan Tangkap, 2012, Statistik Perikanan Tangkap 2011, Kementerian Kelautan dan Perikanan, Jakarta.

FAO, 2012, The State of World Fisheries and Aquaculture (SOFIA), FAO, Roma.

Garner, Bryan A., 2004, Black's Law Dictionary, Thomson \& West, St. Paul Min USA.

Ghofar, A., et al., 2008, Selected Indonesian Fisheries Subsidies: Quantitative and Qualitative Assessment of Policy Coherence and Effectiveness, The Nature Conservation - Coral Triangle, Bali.

Kementerian Kelautan dan Perikanan, 2012, Laporan Akuntabilitas Kinerja Kementerian Kelautan dan Perikanan Tahun 2011, Kementerian Kelautan dan Perikanan, Jakarta.
Porter, Gareth, 2002, Fisheries and the Environment; Fisheries Subsidies and Overfishing: Towards a Structured Discussion, UNEP, Jenewa.

Satria, Arif, 2009, Ekologi Politik Nelayan, LKIS, Yogyakarta.

Schrank, Willian E., 2003, Introducing Fisheries Subsidies: FAO Fisheries Technical Paper, FAO, Roma.

UNEP dan WWF, 2000, Summary Report: The WTO Fishery Subsidies Negotiations; Update and Introductory Briefing for New Delegates, WTO, Jenewa.

Van den Bossche, Peter, 2005, The Law and Policy of the World Trade Organization; Text, Cases and Materials, Cambridge University Press, UK.

Van den Bossche, Peter, et al., 2010, Pengantar Hukum WTO, Yayasan Obor Indonesia, Jakarta.

Westlund, Lena, 2004, Guide for Identifying, Assessing, and Reporting on Subsidies in the Fisheries Sector, FAO, Roma.

WTO, 2007, WTO Analytical Index: Guide to WTO Law and Practice, Cambridge University Press, Cambridge. 
WTO, 2006, Subsidies, Trade and the WTO, 2007, WTO, Geneva.

\section{B. Artikel Jurnal}

Chakrabotry, Debashis, et al., "The Doha Round Negotiations on Subsidy and Countervailing Measures: Potential Implications on Trade Flows in Fishery Sector", Asian Journal of WTO \& International Health Law and Policy, Vol. 6, No. 1, 2011.

GAU, Michael Sheng-ti, "ASIA Perspectives on Fisheries Subsidy Issues and Linkages with Environment", Asian Journal of WTO \& International Health Law and Policy, Vol. 1, No. 1, 2006.

Lewis, Kemi, "Fisheries Subsidies and the WTO: An EU Perspective", CEPMLP Annual Review, Vol. 7, 2003.

Muchlisin, Zainal A., et al., "Analisis Subsidi Perikanan Non BBM di Kabupaten Aceh Besar, Provinsi Nanggroe Aceh Darussalam", Jurnal Depik, Vol. 1, No. 3, 2012.

Sumaila, U.R., et al., "A Bottom-Up Re-Estimation of Global Fisheries Subsidies", Journal of Bioeconomics, Vol. 12, Issue 3, 2010.

"How to Make Progress in Disciplining Overfishing Subsidies", ICES Journal of Marine Science, Vol. 70, 2012.

Young, Margaret, "Fragmentation or Interaction: the WTO, Fisheries Subsidies and International Law", World Trade Review, Vol. 8, Issue 4, 2009.

\section{Sumber Internet}

FAO, "World Review of Fisheries and Agriculture 2010", http://www.fao.org/docreq/013/ i1820e01.pdf., diakses 20 Januari 2014.
Hadi Purnomo, Soen'an, "DKP Tingkatkan Daya Saing Sektor Kelautan Dan Perikanan Untuk Kesejahteraan Masyarakat" http://www. antara.co.id/arc/2009/2/.../dkp-tingkatkandaya-saing-sektor-kelautan-dan-perikananuntuk-kesejahteraan-masyara... - 23k, diakses 15 Desember 2013.

Nobuyaki, Yagi, "Living Marine Resources in the Doha Round of WTO Trade Talks", www. rieti.go.jp/en/bbl/09082101.htm, diakses 20 Januari 2014.

Naoto, Jinji, "Subsidies, Fisheries Management and International Trade", www.rieti.go.jp/ jp/publications/dp/10e023.pdf, diakses 15 Desember 2013.

WTO Ministerial Declaration, "DOHA Work Programme: Annex D on Anti Dumping and Subsidies and Countervailing Measures Including Fisheries Subsidies", WT/ MIN(05)/DEC,http://www.wto.org/english/ thewto_elminist_elmin05_elfinal_annex_e. htm, diakses 20 Januari 2014.

WTO Negotiating Group on Rules, "Draft Consolidated Chair Texts Of The Ad And SCM Agreements: Annex VIII", http://www. wto.org/.../rules_chair_text_nov07_e.doc, diakses 20 Januari 2014.

\section{Media Cetak dan Elektronik}

Halim, Abdul, "Liberalisasi Perikanan dan Nasib Nelayan”, Koran Sindo, 25 Juni 2011.

Noegroho, Anang, "KKP Siap Laksanakan DIPA 2014”, Siaran Pers Pusat Data dan Informasi Kementerian Kelautan Perikanan, 2013. 